\title{
CORRECTION
}

\section{Correction to: Budget Impact Analysis of Fidaxomicin Versus Vancomycin for the Treatment of Clostridioides difficile Infection in the United States}

\author{
Yiling Jiang (D) - Eric M. Sarpong · Pamela Sears · Engels N. Obi
}

Published online: January 16, 2022

(c) Merck \& Co., Inc., Kenilworth, NJ, USA 2022

Correction to: Infect Dis Ther

https://doi.org/10.1007/s40121-021-00480-0

In the original publication of the article the copyright line has been erroneously published as "The Authors" the correct copyright should be Merck \& Co., Inc., Kenilworth, NJ, USA 2021

The copyright line has been corrected in this paper.

Open Access. This article is licensed under a Creative Commons Attribution-NonCommercial 4.0 International License, which permits any non-commercial use, sharing, adaptation, distribution and reproduction in any medium or format, as long as you give appropriate credit to the original author(s) and the source, provide a link to the Creative Commons licence, and indicate if changes were made. The images or other third party material in this article are included in the article's Creative Commons licence, unless indicated otherwise in a credit line to the material. If material is not included in the article's Creative Commons licence and your intended use is not permitted by statutory regulation or exceeds the permitted use, you will need to obtain permission directly from the copyright holder. To view a copy of this licence, visit http:// creativecommons.org/licenses/by-nc/4.0/.
Y. Jiang $(\bowtie)$

Merck Sharp \& Dohme (UK) Ltd., 120 Moorgate, London EC2Y 9AL, UK

e-mail: yiling.jiang1@msd.com

E. M. Sarpong · P. Sears · E. N. Obi

Merck \& Co., Inc., 200 Galloping Hill Road,

Kenilworth, NJ 07033, USA 